\title{
Source of Information and Projected Household Investment Portfolio Performance
}

\section{Postprint.}

For published article see:

Yao, R. \& Lei, S. (2018). Source of Information and Projected Household Investment

Portfolio Performance. Family and Consumer Sciences Research Journal, 46(3), 219-237.

\begin{abstract}
Using modern information economics as the conceptual framework and data from the 2013 Survey of Consumer Finances, this study adopts a decomposition technique to explore the relationship between the primary information source used by U.S. investors and their household investment portfolio performance. The sample includes households with investable assets and those whose primary information source is a financial planner or self-directed sources.

Households that received large amounts of inheritance or gifts within the past year are excluded from this study due to the necessity of additional planning and the associated time commitment to accomplish it. The findings reveal that investors who consult with financial planners have a higher probability of achieving better household investment portfolio performance than selfdirected investors. Results also show that household income and investor' s gender mediated the effect of information source on investment portfolio performance. This study is one of the first to provide empirical evidence of a positive relationship between the service that U.S. financial planners provide and their clients' financial outcome.
\end{abstract}

Keywords: financial behavior; financial planning; information source; portfolio performance; Sharpe ratio 


\section{Introduction}

Individuals and families in the United States are increasingly responsible for making sound investment decisions, which directly affect their wealth accumulation. This responsibility comes from the shift from defined benefit plans to defined contribution plans (U.S. Department of Labor, 2015) and the uncertain future prospects of Social Security benefits (Social Security Board of Trustees, 2015). On the other hand, innovations in the financial market provide investors with a large array of broad and complex financial products (Ho, Palacios, \& Stoll, 2012), which can be difficult for the average investor to understand (Gathergood, 2012). Both the severity and urgency of this increased responsibility over one' s personal finances have generated great interest not only in the financial planning industry (Arends, 2014; Munnell, 2016), but also in academia (Fernandes, Lynch, \& Netemeyer, 2014; Lusardi \& Mitchell, 2011; Yao, Ying, \& Micheas, 2013). In order to make the optimal investment decisions, investors must have access to the full breadth of information and possess the ability to process that information efficiently. In other words, they must have a high level of financial literacy, which many people do not have (Lusardi \& Mitchell, 2011).

Sources of Financial Information

Although the advancement of technology has made information more accessible than ever before, the inundation of such information has mixed effects (Carlson, 2003). The exponential growth in new technologies has enabled investors to access financial information from various sources. However, as individuals face too much information that is not necessarily accurate, useful, or relevant, they may find their decision-making processes impaired and decrease the amount of effort expended as these decisions become increasingly complex (Payne, Bettman, \& Johnson, 1993). Some researchers have gone so far as to suggest that financial 
literacy is not a solution to optimal decision making (e.g., Fernandes et al., 2014). For various reasons, some investors are turning to financial professionals for assistance when making investment decisions. These services must prove their positive relationship with a desired outcome in order to justify their costs and ultimately make financial sense.

Prior literature on the relationship between financial professionals and measurable outcomes is scarce. Existing literature shows mixed evidence of the effect of financial professionals within the United States and in other countries. Many studies that employ U.S. data agree that investors who use brokers are worse off than those who do not use brokers. Analysis from a 1996 to 2002 combined sample from the Financial Research Corporation and Morningstar showed that mutual funds sold through brokered channels underperformed those sold directly to investors in terms of risk-adjusted returns (Bergstresser, Chalmers, \& Tufano, 2009). Similarly, Chalmers and Reuter (2012) examined a set of demographic factors related to financial helpseeking behaviors by analyzing a sample of the Oregon University System employees. Their study found that brokerage customers failed to receive any measurable benefits. In addition, Hackethal, Haliassos, and Jappelli (2012) analyzed data of 32,75 randomly selected individual customers and showed that accounts managed by financial advisors had higher probabilities of losses.

However, studies that rely on data outside of the United States generally speak to the positive benefits of using financial professionals. Shapira and Venezia (2001) found that Israeli investors who used brokers achieved significantly higher annualized returns than self-directed investors did. Findings from Kramer (2012) showed that in the Netherlands, advised investors held portfolios with lower standard deviations and superior gross monthly returns, compared to those who only received execution services. In Germany, Bluethgen, Gintschel, Hackethal, and 
Mueller (2008) found that financial advisors helped investors maintain a stable asset allocation over time and reduced tracking errors. In contrast, Hackethal et al. (2012), using data from a German brokerage firm and a German bank, found that investors who used a financial advisor realized lower Jensen's Alpha and lower Sharpe ratios.

These studies make important contributions to understanding the value of financial professionals as an information source, but are limited in a number of ways. First, analyses are limited by the use of nonrepresentative samples or data that were not collected at the household level. Using data from a specific bank or brokerage firm (e.g., Guercio \& Reuter, 2014;

Hackethal et al., 2012) limits the analysis to assets held at the specific financial institution and, as such, may not reflect the total household investment portfolio. Also, these studies have analyzed only partial portfolios (e.g., Bergstresser et al., 2009), which are unlikely to be reflective of the complete investment portfolio. Additionally, such studies limit their examination to brokers (e.g., Shapira \& Venezia, 2001) or a vague group of financial professionals under the umbrella of “financial advisors" (e.g., Mullainathan, Noeth, \& Schoar, 2012). However, different types of financial professionals have different fields of specialty, are paid differently, and are subject to different compliance standards. Additionally, some studies analyze portfolio diversification and return variability which cannot be compared among investors with different situations. For example, investors with long investment horizons may justifiably have higher return variability.

Total returns and excess returns are common measures of portfolio performance, but since they do not account for portfolio risk, excess returns that adjust for risks are a superior measure (Fama, 1972). Jensen’ s Alpha, Treynor ratio, and Sharpe ratios are commonly used 
measures of excess returns. The Jensen' s Alpha and Treynor ratios use portfolio beta to measure portfolio risk. In order for a comparison among investors to be meaningful, the specific benchmark, which is the base on which the beta was calculated, must be appropriate for all investors. This is usually not the case. In contrast, the Sharpe ratio uses standard deviation as a measure of portfolio risk. As such, it is independent from any benchmark and is a more appropriate measure of risk- adjusted returns when the portfolios under examination are constructed with very different types of investments. Prior studies that utilized the Sharpe ratio typically calculated the ratio in terms of monthly portfolio risks and returns (e.g., Chalmers \& Reuter, 2012; Hackethal et al., 2012). However, a significant limitation of this measure is that investors' investment horizons are usually not the same. Investors with longer investment horizons are likely to have riskier portfolios, so an examination of monthly risks and returns does not accurately reflect the appropriateness of their portfolio. Therefore, it is preferential to consider investment horizons when comparing Sharpe ratios.

In this study, we further the understanding of the relationship between financial planners and a measurable outcome of their clients by employing nationally representative household-level data and conducting a close examination of household investment performance. Specifically, the purpose of this study was to examine the relationship between using financial planners as the saving and investment information source and the projected portfolio Sharpe ratio based on portfolio risks and returns as well as investors' investment horizons. The investment portfolios used in our study are more comprehensive than those used in previous studies and include all investable financial and nonfinancial assets.1 We also compare the portfolio performance between self- directed investors and investors who use financial planners as their primary source of information when making investment decisions. 
Additionally, we provide explanations of the key findings and provide directions for future research.

Factors related to investment performance

Prior research has identified other factors that are associated with portfolio performance. Since portfolio performance is largely dependent on portfolio allocation (Brinson, Hood, \& Beebower, 1986), reviewing literature concerning factors influencing portfolio allocation would also be beneficial.

Economic Situations

The effect of income and wealth on portfolio allocation has been thoroughly studied. Results from research showed that income and wealth were related to portfolio allocation (Anderson, 2013; Goetzmann \& Kumar, 2008; Roche, Tompaidis, \& Yang, 2013) and portfolio performance (Calvet, Campbell, \& Sodini, 2007). For example, Anderson (2013) discovered a positive relationship between the proportion of stocks allocated in risky assets and the level of household wealth and income. In addition, Calvet et al. (2006) concluded that households with higher incomes and more wealth achieved better portfolio performance, measured by the Sharpe Ratio.

Homeownership and business ownership were found to affect portfolio allocation. The crowd-out effect of self-owned housing resulted in a smaller proportion of stocks in the portfolio (Cocco, Gomes, \& Maenhout, 2005). The effect of business ownership was mixed, possibly due to different definitions of risky assets. According to Xiao, Alhabeeb, Hong, and Haynes (2001), family business owners were more likely than nonowners to own risky assets including risky financial assets (such as stocks, bonds, and mutual funds) and risky nonfinancial assets (such as real estate). Results from Faig and Shum (2002) showed that business owners tended to "have 
significantly safer portfolios.” In their study, risky assets included stocks, bonds, IRAs and thrift-type accounts, cash value of whole life insurance, other managed assets, and other financial assets.

Demographic Characteristics

Several empirical studies have highlighted the influence of age, education, race, and gender on portfolio performance. Studies on the effect of age on portfolio allocation have shown inconsistent findings. Yogo (2016) found that the share of stock in retirement portfolios increased over time for a total of 2\% for every 10 years. Flavin and Yamashita (2011) concluded that older investors held larger proportions of stocks in their portfolio. However, Coile and Milligan (2009) showed that the proportion of risky assets (including principal residences, vehicles, financial assets, businesses, and real estate) in their portfolio decreased as investors aged.

Research has shown a positive effect of education on the share of stocks in investors' portfolios (Abreu \& Mendes, 2010; Christiansen, Joensen, \& Rangvid, 2008; Lai, 2006). For example, women held a lower proportion of stocks in their portfolios than men (Sunden \& Surette, 1998). Disparity also existed in portfolio allocation among different races. On average, White investors held more risky assets (including stock, stock mutual funds, stock, or stock funds) than investors of other races (Gutter \& Fontes, 2006).

Perceptions and Preferences

The majority of research examining the relationship between different levels of risk tolerance and the proportion of risky assets in the portfolio has concluded that investors with a higher level of risk tolerance were more likely to have a riskier portfolio (e.g., Corter \& Chen, 2006; Dulebohn, 2002). Much research has affirmed the influence of investment horizons on 
portfolio performance (Hodges, Taylor, \& Yoder, 1997) and allocation (Butler \& Domian, 1991). For example, Hodges et al. (1997) found that individual investors with longer expected investment horizons generally enjoyed better portfolio performance, measured by Sharpe Ratios. According to Butler and Domian (1991), individual investors with longer investment horizons invested more in stocks than in bonds. The "time diversification" lessened the risk of reaching investment objectives for the long-term investment horizon. Prior studies agreed that poor selfreported health was related to low risk-taking in portfolio allocation (Berkowitz \& Qiu, 2006; Edwards, 2008; Goldman \& Maestas, 2013; Love \& Smith, 2010, Rosen \& Wu, 2004).

\section{Background and Theory}

Neoclassical economic theory contends that individuals must have complete information, as well as the ability to identify relevant and accurate information, in order to make rational decisions. Early developments of information economics (e.g., Stigler, 1961) relaxed the assumption of perfect information and proposed that the alternative with equal marginal cost and marginal benefit would be chosen. However, modern information economics (Akerlof, 1970; Rothschild \& Stiglitz, 1976; Spence, 1973, 1974) recognize that information is significantly different from other goods in that it is imperfect, costly, asymmetric, and inefficiently distributed. Therefore, many neoclassical economic results do not hold when information is involved and approaches that compare marginal cost and marginal benefit are impractical.

Information Bundling

Given the characteristics of information, bundling a large number of information goods and selling them as a group is an important method for taking advantage of information 
(Bakos \& Brynjolfsson, 1999). Because information is an additive resource that improves through use (Kubiszewski, Farley, \& Costanza, 2010), regular searches tend to increase efficiency. With their expertise and experience, financial professionals can identify useful and relevant information more efficiently than investors (Monti, Pelligra, Martignon, \& Berg, 2014). They enjoy the benefit of economies of scale by selling the same information bundle to multiple investors with very little marginal cost. In contrast, investors who, whether unwilling or unable, do not regularly search for information are less efficient in such searches.

Consequently, some investors are not fully informed at the point of decision making and information bundles provided by financial professionals can help them fill the information void. Sources of Information

Different financial professionals have different areas of specialty. For example, financial planners assist clients in meeting their financial goals through planning at a comprehensive perspective and managing their resources. Other financial professionals either have a specialized set of skills or are paid differently. For example, accountants are more specialized in tax matters, while investment advisers provide advice about securities (The Office of Investor Education and Advocacy, 2012). Brokers are licensed to sell and buy stocks and generally collect commission on their sales of products (CFP Board of Standards, 2017). As Chalmers and Reuter (2012) pointed out, they may also have conflicts of interest (e.g., brokers collect commissions on products sold). As a result, some financial professionals may be less efficient than financial planners as an information source. Although self-directed investors can search for information with little monetary costs and no conflicts of interest, they do not have the same access to, or the same ability to process, financial information. Hypotheses 
The information bundle provided by financial professionals comes with a cost so the bundle must provide monetary value to investors. Better portfolio performance produces more wealth and is therefore more desirable. Previous literature has indicated that some control variables, such as investor' s demographic and economic characteristics, also affect household portfolio performance (e.g., Abreu \& Mendes, 2010; Anderson, 2013). These variables may affect investors' decision to search information from financial planners and, as such, affect their portfolio performance. Based on information economics theory and literature, we hypothesize that:

- The projected investment portfolio performance is better for investors who use financial planners than for self-directed investors; and

- Some control variables serve as moderating factors in the relationship between information source and projected investment portfolio performance.

\section{Methodology}

Data

This study utilizes the 2013 Survey of Consumer Finances (SCF) dataset to test the potential effect of using different information resources on household investment portfolio performance. The SCF is a cross-sectional survey conducted triennially and supported by the Board of Governors of the Federal Reserve System in cooperation with the Statistics of Income Division of the Internal Revenue Service. The SCF data are nationally representative and provide a large array of information on individuals' demographic and economic characteristics as well as their expectations and preferences. More detailed descriptions of the data can be found in Bricker et al. (2014). 
The SCF provides information on asset allocation of each household instead of information on the risk and return of each specific asset held. Although more accuracy would be achieved using information on specific assets, the contribution to the accuracy is likely to be marginal. According to Brinson et al. (1986), asset allocation explained, on average, 93.6\% of the portfolio performance. Individual security selection and market timing made up the remainder of the portfolio' s performance. Our measure captures the effect of professional advice on asset allocation and market timing.

In order to calculate the expected rates of return and standard deviations on asset classes, we extract data from various sources. For example, we use data provided by Ibbotson Associates, owned by Morningstar, Inc., to calculate the expected rate of return and standard deviation of cash and cash equivalent assets, stocks, and bonds. We use rates published by the Internal Revenue Service (IRS) to calculate the expected rate of return and standard deviation of loans to friends.

The total sample size for the 2013 SCF was 6,015 . Since the purpose of this study was to investigate the relationship between information sources and household investment portfolio performance, the study excludes households with no investable assets, as well as households who do not seek information when making savings and investment decisions. Because of the different expertise, pay arrangements and standards of care (suitability vs. fiduciary) between financial planners and other financial professionals, this study also excluded households who primarily consult with other financial professionals (e.g., accountants) when making investment decisions. In addition, the SCF does not provide information to separate investors' accumulated assets from their inherited assets or received gifts. 
After major life events, such as receiving a large inheritance, investors' consumption patterns and financial goals often change (Tokat \& Wicas, 2007) and their investment portfolios should be adjusted accordingly. Even if portfolios are not adjusted immediately after receiving such assets, the annual portfolio review must be conducted to reflect the investor' $s$ new financial status and goals (Tokat \& Wicas, 2007). Consequently, households that received large amounts of inheritances or gifts within the past year are excluded from this study. After the sample selection, the final sample size for this study is 3,494 .

The SCF data are complex due to the sample design, multiple imputation of missing data, and issues related to confidentiality and disclosure. The sample consists of a standard, geographically based random sample and a list sample with an oversampling of wealthy households. The oversampling procedure provides more precise wealth estimates (especially for rarely held assets) and a method of correcting for the higher rate of nonresponse among wealthy households. This study uses weights recommended by the Federal Reserve in the descriptive analysis in order to combine information from the two samples and determine estimates for the full population. To address the issue of missing data on survey responses, the SCF incorporates five estimates of missing data to allow for an estimate of the uncertainty attributable to this type of nonresponse (Ackerman, Fries, \& Windle, 2012). In the multivariate analysis, we use the "repeated-imputation inference" method to include all five estimates. We also use the 999 bootstrap replicate weights provided by the SCF to compute estimates of sampling variance in order to address the confidentiality and disclosure concerns.

When collecting and documenting the responses, the SCF designated the man in a mixed-sex couple or the older individual in a same-sex couple as the head of the household, no matter who responded to the questions. If data were collected from 
someone other than the designated head, then "all data for the two members of the couple were systematically swapped" (The Federal Reserve, 2014). Thus, in order to make the responses consistent with their respondents, in this study, we switched the two individuals back as needed.

Construction of the Key Variables

Measure of investment portfolio performance. The dependent variable in this study is projected investment portfolio performance, measured by the Sharpe ratio of the household investment portfolio and based on the expected risk and return of the portfolio given the household' $\mathrm{s}$ investment horizon. The Sharpe ratio provides a risk-adjusted portfolio return in excess of the risk-free rate of return. Portfolios with a higher Sharpe ratio are considered to have better performance. The Sharpe ratio is calculated using the following formula:

$$
\text { Sharpe Ratio }=\frac{r_{p-} r_{f}}{\sigma_{p}}
$$

where $\mathrm{rp}=$ portfolio rate of return, $\mathrm{rf}=$ risk-free rate of return, and $\sigma_{p}=$ portfolio standard deviation

The portfolio rate of return is the weighted average of the rate of return of each asset in the portfolio, which is calculated as:

$$
r_{p}=\sum_{i=1}^{n} w_{i} r_{i}
$$

where $\mathrm{w}_{\mathrm{i}}=$ weight of each asset in an investment portfolio, $\mathrm{ri}=$ rate of return for each asset, and $\mathrm{n}=$ number of assets in an investment portfolio.

Portfolio standard deviation is the square root of portfolio variance, which is calculated using the following matrix: 


$$
\sigma_{p}^{2}=\left[w_{1} 1 \ldots w_{1} n\right] *\left[\begin{array}{ccc}
\sigma_{1}^{2} & \ldots & \sigma_{1 n} \\
\vdots & \ddots & \vdots \\
\sigma_{n 1} & \ldots & \sigma_{n}^{2}
\end{array}\right] *\left[\begin{array}{c}
w_{1} \\
\vdots \\
w_{n}
\end{array}\right]
$$

where wi $=$ weight of each asset in an investment portfolio, $\mathrm{r} 2=$ variance for each asset, rii $=$ covariance for two assets in an investment portfolio, and $n=$ number of assets in an investment portfolio

To calculate the Sharpe ratio, it is first important to know the asset classes and the weight of each asset (wi) in the household investment portfolio in order to determine the $r_{p}$ and $\sigma_{p}$. In the SCF dataset, some investment accounts include a mix of various types of assets, so we reclassified these assets into asset classes based on their characteristics and the properties of their return and risk. The weight of each class of asset $\left(\mathrm{w}_{\mathrm{i}}\right)$ is calculated, followed by the expected rate of return $\left(\mathrm{r}_{\mathrm{i}}\right)$ and standard deviation $\left(\mathrm{r}_{\mathrm{i}}\right)$ of each class of asset in the portfolio. The geometric mean of the return rates for each asset class from 1926 to 2012 serves as a proxy for the rate of return that each individual is expected to earn for holding that class of asset.

We use a similar procedure to calculate the standard deviation for each asset class as a proxy for the standard deviation that each individual investor is expected to bear for holding those assets. Based on each investor' s investment horizon, the annual, 5-year, 10-year, and 20year rate of returns (for multiyear periods, the moving averages were used) and the standard deviation of each asset class is assigned for each investor' s portfolio.

We assume that investors follow the "buy-and-hold strategy" meaning that they hold their investment portfolio until the end of their investment horizon. This strategy is appropriate for self-directed investors and advised investors, regardless of their portfolio size. It is ideal to have information about the specific assets owned in each household and their specific investment 
strategies carried out over time, but such data are not available. To mitigate this simplification, the respective risk and return for each type of assets are used in the calculation of the portfolio Sharpe ratio.

Information source and controlled variables. Our main independent variable is investors' source of investment information. It is categorized into two groups: (1) self-directed; and (2) using financial planners. The self-directed category refers to investors who use information sources with little or no monetary cost, such as consulting with friends/relatives and/or a spouse/partner, conducting personal research or calling around, belonging to investment clubs, or through accessing media. The financial planner category includes individuals who use financial planners as their primary information source when making investment decisions.

Control variables include three categories: (1) household economic situations; (2) respondent demographic characteristics; and (3) respondents' expectations and preferences. Economic situations at the household level include income (quartiles), net worth (quartiles), homeownership, business ownership, and ownership of cash value of life insurance. Demographic characteristics for the respondents include age, gender, race/ethnicity, education, marital status, employment status, and presence of dependent children. Respondents expectations and preferences include self-perceived health, subjective risk tolerance, investment horizon, and inheritance expectation.

Data analysis. The dependent variable, Sharpe Ratio, is a continuous variable. Results from the K-S test for normality $(\mathrm{D}=0.40)$, Cramer-von Mises test $(\mathrm{W}-\mathrm{Sq}=854.9)$, Anderson-Darling test (4,056.88), the skewness (11.3), and the kurtosis (199.1) statistics, as well as the Q-Q plot, suggest that categorizing the dependent variable into several groups for conducting an ordered 
logistic regression is preferential. The Sharpe ratio is coded into quintiles $(1=$ lowest and $5=$ highest).

Since some control variables may affect investor' $\mathrm{s}$ investment performance, we adopt a decomposing method to isolate the effect of information source on household investment portfolio performance. We first regress Sharpe ratio on control variables in a reduced model. Then, we add information source as an independent variable into an intermediate model. Finally, we add all interaction terms between the information source variable and the control variables. The full model provides evidence on whether the source of information in and of itself contributed to the difference in portfolio performance between the two information sources groups, or the differences are moderated by factors that are also related to the choice of the information source. This method can date back to Jackson and Lindley (1989) who examined wage discrimination between men and women. Similar techniques have been used by other studies since then (Fisher \& Yao, 2017; Fontes \& Kelly, 2013; Gutter, Fox, \& Montalto, 1999).

We use a likelihood ratio test to examine the information source differences in portfolio performance by comparing the full interaction model and the reduced model. A significant likelihood ratio would indicate that portfolio performance was different between self-directed investors and those who used financial planners. We then further decomposed this betweengroup difference into the constant effect and the coefficient effect (Jackson \& Lindley, 1989, pp. $517-520)$. The constant effect refers to the difference in the portfolio performance only due to the difference in information sources. There would be a significant constant effect if the estimated coefficient of the information source variable in the full interaction model was significant. The coefficient effect refers to the effect of information sources on portfolio 
performance through other factors (the control variables). In order to determine the significance of the coefficient effect, we used a likelihood ratio test to compare the full interaction model and the intermediate model. A significant likelihood ratio would indicate the existence of the coefficient effect.

\section{Results}

Sample Statistics

As shown in Table 1, the majority (77.76\%) of respondents in the sample sought information on their own when making saving and investment decisions. Respondents seeking information from planners achieved significant higher projected Sharpe Ratio $($ mean $=0.89)$ than self-directed investors $($ mean $=0.33)$. Significant differences existed between financial planner users and selfdirected investors. For example, investors who used financial planners as their information source reported higher household incomes (mean $=\$ 135,269)$ than self-directed investors (mean $=\$ 87,602)$. These amounts are high because our sample excluded households who did not have investable assets and their mean household income was $\$ 18,974$.

Logistic Regression Results

After controlling for other variables, information source was significantly related to household investment portfolio performance. See Table 2. Compared with self-directed investors, households that used financial planners as an information source when making saving and investment decisions were $16.0 \%$ more likely (estimated coefficient $=0.148)$ to achieve higher Sharpe ratios in the intermediate model. This result was consistent with the first hypothesis. The test of the information source variable and the set of interaction terms showed a high significance 
$(\mathrm{p}<.001)$. Therefore, we proceeded with the procedure to decompose this total betweengroup difference in portfolio performance.

The decomposition showed a significant constant effect $(p=.028)$ and coefficient effect $(\mathrm{p}<.001)$. These results indicated that information source not only affected household investment portfolio performance directly but also through the control variables. This result supported the second hypothesis. In the full interaction model, the estimated coefficient of the information source indicator variable was significant and positive, indicating a positive constant effect of using financial planners on household investment portfolio performance.

As shown in the full interaction model, income and gender mediate the relationship between information source and household investment portfolio performance. See Table 2. Among self-directed investors, those in the highest income quartile were 2.4 times more likely (estimated coefficient $=1.212$ for the main effect of the highest income quartile) than those in the lowest income quartile to achieve better portfolio performance. On the other hand, among investors who used financial planners, those in the highest income quartile were $51.1 \%$ more likely (estimated coefficient $=0.799$ for the interaction effect of highest income quartile and using financial planner2). Please see the Appendix.

Similarly, compared to self-directed male investors, self-directed female investors were $24.4 \%$ more likely to achieve better portfolio performance (estimated coefficient $=0.218$ for the main effect of being a female). In addition, among investors who used financial planners, females were $18.9 \%$ less likely than males to achieve better portfolio performance. The lack of significance of other interaction terms is evidence that other variables did not mediate the relationship between information source and household investment portfolio performance. 


\section{Discussion}

Using modern information economics as the conceptual framework and data from the 2013 Survey of Consumer Finances, this study adopted a decomposition technique to explore the relationship between the primary information source used by U.S. investors and their household investment portfolio performance. The primary information source was a financial planner or self-directed sources.

Consistent with the hypotheses, the empirical results revealed evidence that the portfolio performance was better for investors who used financial planners than for self-directed investors and that the relationship between information source and portfolio performance was partially mediated by household income and gender. Information economics suggests that one way that financial planners can add value to their clients is to take advantage of the unique characteristics of information in the information search process. The findings of this study have confirmed that the service of financial planners is positively related to a client' s financial life.

One result that is a concern is that females who used financial planners were less likely to achieve a better Sharpe ratio than males who used financial planners. We also noticed that investors with a higher risk tolerance and a longer investment horizon were more likely to have higher Sharpe ratios. We conducted additional analysis and found that compared to males, females were less risk tolerant and had shorter investment horizons. Investors with low risk tolerance and short horizons are limited to products with lower risks. Although low portfolio performance may be due to a lack of attention on the part of financial planners who helped construct the portfolios, there are reasons to be cautious before jumping to these conclusions. Theoretically, there is an optimal portfolio return for every level of risk. We might question whether the observed effect of risk tolerance and investment horizon is due to a lack of selection 
of investment products among people with low risk tolerance and short horizons. This, in turn, would lead to underdiversified portfolios that are more likely to have a higher standard deviation, which reduces the Sharpe ratio. It is likely that the effect of risk tolerance and investment horizon on portfolio performance is a combination of both of these factors.

Family and consumer science researchers who are committed to help households make informed financial decisions could focus their efforts on investigating investment strategies that help households with low risk tolerance and shorter investment horizons diversify their portfolio to minimize their risks and, at the same time, invest in higher-return assets. Financial planners should also devote time and effort to helping these clients explore existing low-risk products and construct portfolios that can achieve better risk-adjusted returns.

The use of information source is a choice and, therefore, it is endogenous. Without relevant time series data (currently unavailable) or random experiments (introducing potential moral hazards), establishing a causal relationship between financial advice and portfolio performance is almost impossible. However, identifying the relationship between information source and portfolio performance is the first step in quantitatively assessing the value of financial planners. In order to reduce the effect of such self-selection bias, this study controlled factors affecting the use of financial planners such as income, wealth, age, gender, education, race, and expecting inheritance or gifts (Elmerick, Montalto, \& Fox, 2002) as well as the interaction terms between information source and these variables.

Prior research has found that investors who consulted with financial professionals were less financially literate (Hung \& Yoong, 2010). Assuming that individual financial literacy in the absence of advice from a financial planner positively contributes to portfolio performance, the observed differences in projected Sharpe ratios between advised and self-directed investors in 
this study may be an underestimation of the value of financial planners as an information source. Investors are financially unsophisticated for various reasons, whether from an inability to learn or due to the high opportunity costs of learning. Regardless of the specific reasons, consulting with financial planners when making investment decisions relates positively to portfolio performance.

Our study is one of the first to provide empirical evidence of a positive relationship between the service that financial planners provide and their clients' financial outcome in the United States using a nationally representative household-level data. We have contributed to the existing literature by adopting a decomposition technique to analyze the effect of using financial planners on projected household portfolio Sharpe ratio. Our definition of household investment portfolio, including all investable financial and nonfinancial assets, was more comprehensive than prior studies. Our contribution also includes a direct comparison of portfolio performance among investors using different sources of information when making investment decisions. Future research can enhance this line of study by considering the costs of engaging financial planners and the tax consequences of security sales to explore whether the excess return is still positive after the transaction costs and taxes.

\section{Notes}

${ }^{1}$ These assets include cash and cash equivalents (checking accounts, money market deposit accounts, money market mutual funds, call accounts at brokerages, CDs, and savings bonds), stocks (publicly traded stocks and stock mutual funds), bonds (tax-free bond mutual funds, government bond mutual funds, other bond mutual funds, state and local bonds, mortgagebacked bonds, U.S. government and government agency bonds and bills, corporate and foreign 
bonds), real estates for investment purposes, business interests, and assets in IRAs, annuities, trusts, account type pension plans that are invested in stocks, bonds, real estates, hedge funds, private equity, real estate investment trusts (REITS), and business interests. Primary residence was not included because it is, at least partially, a consumption asset. Other financial assets and non-financial assets include loans to friends, commodities, gold, silver, other metal, livestock, and collectibles.

${ }^{2} \mathrm{Y}=\beta 0+1.212 \mathrm{Inc} 4+1.581 \mathrm{FP}-0.799 \mathrm{Inc} 4 * \mathrm{FP}$

\section{References}

Abreu, M., \& Mendes, V. (2010). Financial literacy and portfolio diversification. Quantitative Finance, 10(5), 515 - 528. https://doi.org/10.1080/14697680902878105

Ackerman, R. A., Fries, G., \& Windle, R. A. (2012). Changes in US family finances from 2007 to 2010: Evidence from the Survey of Consumer Finances. Federal Reserve Bulletin, 100, $1-80$.

Akerlof, G. (1970). The market for "lemons" : Qualitative uncertainty and the market mechanism. Quarterly Journal of Economics, 84, 488 - 500. https://doi.org/10.2307/1879431

Anderson, A. (2013). Trading and under-diversification. Review of Finance, 17, 1699 - 1741. doi: $10.1093 /$ rof/rfs044.

Arends, B. (2014). Our next big crisis will be a retirement crisis. Retrieved January 25, 2017, from http://www.marketwatch.com/story/our-next-big-crisis-will-be-a-retirement-crisis2014-03-03

Bakos, Y., \& Brynjolfsson, E. (1999). Bundling information goods: Pricing, profits, and efficiency. Management Science, 45, 1613 - 1630. https://doi.org/10.1287/mnsc.45.12.1613

Bergstresser, D., Chalmers, J. M., \& Tufano, P. (2009). Assessing the costs and benefits of brokers in the mutual fund industry. Review of Financial Studies, 22, $4129-4156$. https://doi.org/10.1093/rfs/ hhp022

Berkowitz, M. K., \& Qiu, J. (2006). A further look at household portfolio choice and health status. Journal of Banking \& Finance, 30, 1201 - 1217.

Bluethgen, R., Gintschel, A., Hackethal, A., \& Mueller, A. (2008). Financial advice and individual investors' portfolios. SSRN Electronic Journal, https://doi.org/10.2139/ssrn.968197 
Bricker, J., Dettling, L. J., Henriques, A., Hsu, J. W., Moore, K. B., Sabelhaus, J., et al. (2014). Changes in U.S. family finances from 2010 to 2013: Evidence from the survey of consumer finances. Federal Reserve Bulletin, 100, 1 - 41. Retrieved March 20, 2017, from http://www.federalreserve.gov/pubs/ bulletin/2014/articles/scf/scf.htm

Brinson, G. P., Hood, L. R., \& Beebower, G. L. (1986). Determinants of portfolio performance. Financial Analysts Journal, 42, 39 - 44. https://doi.org/10.2307/4478947

Butler, K. C., \& Domian, D. L. (1991). Risk, diversification, and the investment horizon. The Journal of Portfolio Management, 17(3), 41 - 47. https://doi.org/10.3905/jpm.1991.409334

Calvet, L. E., Campbell, J. Y., \& Sodini, P. (2007). Down or out: Assessing the welfare costs of household investment mistakes. Journal of Political Economy, 115, 707 - 747. doi: $10.1086 / 524204$.

Carlson, C. N. (2003). Information overload, retrieval strategies and Internet user empowerment. In L. Haddon (Ed.), Proceedings the good, the bad and the irrelevant (pp. 169 - 173). Helsinki, Finland: University of Art and Design.

CFP Board of Standards. (2017). Type of financial planners and advisors. Washington, DC: CFP Board of Standards, Inc. Retrieved November 1, 2017 from http://www.letsmakeaplan.org/other-resource s/types-of-financial-advisors

Chalmers, J., \& Reuter, J. (2012). Is conflicted investment advice better than no advice? Revision of NBERWorking Paper, no. 18158. Cambridge, MA: National Bureau of Economic Research. https://doi. org/10.3386/w18158

Christiansen, C., Joensen, J. S., \& Rangvid, J. (2008). Are economists more likely to hold stocks? Review of Finance, 12(3), 465 - 496. https://doi.org/10.1093/rof/rfm026

Cocco, J. F., Gomes, F. J., \& Maenhout, P. J. (2005). Consumption and portfolio choice over the life cycle. Review of Financial Studies, 18(2), 491 - 533. https://doi.org/10.1093/rfs/hhi017

Coile, C., \& Milligan, K. (2009). How household portfolios evolve after retirement: The effect of aging and health shocks. Review of Income and Wealth, 55(2), $226-248$. https://doi.org/10.1111/j.1475-4991.2009.00320.x

Corter, J. E., \& Chen, Y.-J. (2006). Do investment risk tolerance attitudes predict portfolio risk? Journal of Business and Psychology, 20(3), 369 - 381. https://doi.org/10.1007/s10869-005-9010-5

Dulebohn, J. H. (2002). An investigation of the determinants of investment risk behavior in employer- sponsored retirement plans. Journal of Management, 28(1), 3 - 26. https://doi.org/10.1177/ 014920630202800102

Edwards, R. D. (2008). Health risk and portfolio choice. Journal of Business \& Economic Statistics, 26, $472-485$.

Elmerick, S. A., Montalto, C. P., \& Fox, J. J. (2002). Use of financial planners by U.S. households. Financial Services Review, 11, 217.

Faig, M., \& Shum, P. (2002). Portfolio choice in the presence of personal illiquid projects. The Journal of Finance, 57(1), 303 - 328. https://doi.org/10.1111/1540-6261.00423

Fama, E. F. (1972). Components of investment performance. The Journal of Finance, 27, 551 567. https://doi.org/10.2307/2978261 
Fernandes, D., Lynch, J. G., Jr, \& Netemeyer, R. G. (2014). Financial literacy, financial education, and downstream financial behaviors. Management Science, 60, 1861 - 1883. https://doi.org/10.1287/ mnsc.2013.1849

Fisher, P. J., \& Yao, R. (2017). Gender differences in financial risk tolerance. Journal of Economic Psychology, 61, 191 - 202. https://doi.org/10.1016/j.joep.2017.03.006

Flavin, M., \& Yamashita, T. (2011). Owner-occupied housing: Life-cycle implications for the household portfolio. The American Economic Review, 101(3), 609 - 614. https://doi.org/10.1257/aer. 101.3.609

Fontes, A., \& Kelly, N. (2013). Factors affecting wealth accumulation in hispanic households: A comparative analysis of stock and home asset utilization. Hispanic Journal of Behavioral Sciences, 35 (4), 565 - 587. https://doi.org/10.1177/0739986313500467

Gathergood, J. (2012). Self-control, financial literacy and consumer over-indebtedness. Journal of Economic Psychology, 33, 590 - 602. https://doi.org/10.1016/j.joep.2011.11.006

Goetzmann, W. N., \& Kumar, A. (2008). Equity portfolio diversification. Review of Finance, 12(3), 433 - 463. https://doi.org/10.1093/rof/rfn005

Goldman, D., \& Maestas, N. (2013). Medical expenditure risk and household portfolio choice. Journal of Applied Econometrics, 28, 527 - 550.

Guercio, D. D., \& Reuter, J. (2014). Mutual fund performance and the incentive to generate alpha. The Journal of Finance, 69, 1673 - 1704. https://doi.org/10.1111/jofi.12048

Gutter, M. S., \& Fontes, A. (2006). Racial differences in risky asset ownership: A two-stage model of the investment decision-making process. Journal of Financial Counseling \& Planning, 17(2), $64-78$.

Gutter, M. S., Fox, J. J., \& Montalto, C. P. (1999). Racial differences in investor decision making. Financial Services Review, 8(3), 149 - 162. https://doi.org/10.1016/S10570810(99)00040-2

Hackethal, A., Haliassos, M., \& Jappelli, T. (2012). Financial advisors: A case of babysitters? Journal of Banking \& Finance, 36, 509 - 524. https://doi.org/10.1016/j.jbankfin.2011.08.008

Ho, T., Palacios, M., \& Stoll, H. (2012). Regulatory principles for the financial system. Journal of Derivatives, 20, 19 - 37. https://doi.org/10.3905/jod.2012.20.1.019

Hodges, C. W., Taylor, W. R., \& Yoder, J. A. (1997). Stocks, bonds, the Sharpe ratio, and the investment horizon. Financial Analysts Journal, 53(6), $74-80$. https://doi.org/10.2469/faj.v55.n2. 2250

Hung, A., \& Yoong, J. (2010). Asking for help: Survey and experimental evidence on financial advice and behavior change. RAND Labor and Population Working Paper, no. WR-7141. Santa Monica, CA. https://doi.org/10.2139/ssrn.1532993

Jackson, J. D., \& Lindley, J. T. (1989). Measuring the extent of wage discrimination: A statistical test and a caveat. Applied Economics, 21(4), 515 - 540. https://doi.org/10.1080/758519717

Kramer, M. M. (2012). Financial advice and individual investor portfolio performance. Financial Management, 41, 395 - 428. https://doi.org/10.1111/j.1755-053X.2012.01185.x

Kubiszewski, I., Farley, J., \& Costanza, R. (2010). The production and allocation of information as a good that is enhanced with increased use. Ecological Economics, 69, 1344 - 1354. https://doi.org/10. 1016/j.ecolecon.2010.02.002 
Lai, C. W. (2006). Determinants of portfolio efficiency losses in US self-directed pension accounts. Journal of Family and Economic Issues, 27(4), 601 - 625. https://doi.org/10.1007/s10834 - 006-9033-8 Love, D. A., \& Smith, P. A. (2010). Does health affect portfolio choice? Health Economics, 19, 1441 - 1460.

Lusardi, A., \& Mitchell, O. S. (2011). Financial literacy and retirement planning in the United States. Journal of Pension Economics and Finance, 10, 509 - 525. https://doi.org/10.1017/s147474721100045x Monti, M., Pelligra, V., Martignon, L., \& Berg, N. (2014). Retail investors and financial advisors: New evidence on trust and advice taking heuristics. Journal of Business Research, 67, 1749 - 1757. https://doi.org/10.1016/j.jbusres.2014.02.022

Mullainathan, S., Noeth, M., \& Schoar, A. (2012). The market for financial advice: An audit study. NBER Working Paper, no. 17929. Cambridge, MA: National Bureau of Economic Research. https://doi. org/10.3386/w17929

Munnell, A. H. (2016). Defined benefit plans earn higher returns than defined contribution plans. Retrieved May 15, 2017, from http://www.marketwatch.com/story/defined-benefit-plansearn-higher-re turns-than-defined-contribution-plans-2016-01-08

Payne, J. W., Bettman, J. R., \& Johnson, E. J. (1993). The adaptive decision maker. New York, NY: Cambridge University Press. https://doi.org/10.1017/CBO9781139173933

Roche, H., Tompaidis, S., \& Yang, C. (2013). Why does junior put all his eggs in one basket? A potential rational explanation for holding concentrated portfolios. Journal of Financial Economics, 109(3), 775 - 796. https://doi.org/10.1016/j.jfineco.2013.03.016

Rosen, H. S., \& Wu, S. (2004). Portfolio choice and health status. Journal of Financial Economics, 72, $457-484$.

Rothschild, M., \& Stiglitz, J. (1976). Equilibrium in competitive insurance markets: An essay on the economics of imperfect information. The Quarterly Journal of Economics, 90, 629 649. https://doi. org/10.2307/1885326

Shapira, Z., \& Venezia, I. (2001). Patterns of behavior of professionally managed and independent investors. Journal of Banking \& Finance, 25, 1573 - 1587. https://doi.org/10.1016/s0378-4266(00) 00139-4

Social Security Board of Trustees. (2015). The 2015 annual report of the board of trustees of the federal old- age and survivors insurance and federal disability insurance trust funds. Retrieved December 5, 2016 from https://www.ssa.gov/oact/tr/2015/tr2015.pdf

Spence, A. M. (1974). Market signaling: Informational transfer in hiring and related screening processes (pp. 200 - 201). Cambridge, MA: Harvard University Press.

Spence, M. (1973). Job market signaling. The Quarterly Journal of Economics, 87, 355 - 374. https://doi. org/10.2307/1882010

Stigler, G. J. (1961). The economics of information. Journal of Political Economy, 69, 213 225. https:// doi.org/10.1086/258464

Sunden, A. E., \& Surette, B. J. (1998). Gender differences in the allocation of assets in retirement savings plans. The American Economic Review, 88, 207 - 211. The Federal Researve. (2014). Code book for 2013 survey of consumer finances. Retrieved from March 13, 2017 http://www.federalreserve.gov/econresdata/scf/scfindex.htm

The Office of Investor Education and Advocacy. (2012). Investment advisers: What you need to know before choosing one. Washington, DC: U.S. Securities and Exchange Commission. 
Retrieved November 1, 2017, from https://www.sec.gov/reportspubs/investorpublications/investorpub sinvadvisershtm.html

Tokat, Y., \& Wicas, N. W. (2007). Portfolio rebalancing in theory and practice. The Journal of Investing, 16(2), 52 - 59. https://doi.org/10.3905/joi.2007.686411

United States Department of Labor. (2015). Private pension plan bulletin historical tables and graphs 1975 - 2013. Retrieved May 24, 2017, from https://www.dol.gov/sites/default/files/ebsa/researc hers/statistics/retirementbulletins/historicaltables.pdf

Xiao, J. J., Alhabeeb, M. J., Hong, G. S., \& Haynes, G. W. (2001). Attitude toward risk and risk taking behavior of business owning families. Journal of Consumer Affairs, 35(2), 307 325. https://doi.org/ 10.1111/j.1745-6606.2001.tb00116.x

Yao, R., Ying, J., \& Micheas, L. (2013). Determinants of defined contribution plan deferral. Family and Consumer Sciences Research Journal, 42, 55 - 76. https://doi.org/10.1111/fcsr.12038

Yogo, M. (2016). Portfolio choice in retirement: Health risk and the demand for annuities, housing, and risky assets. Journal of Monetary Economics, 80, 17 - 34. https://doi.org/10.1016/j.jmoneco.2016. 04.008 


\begin{tabular}{|c|c|c|c|}
\hline & \multirow[b]{2}{*}{$\begin{array}{l}\text { Total Sample } \\
N=3,494\end{array}$} & \multicolumn{2}{|c|}{ Information Source } \\
\hline & & $\begin{array}{l}\text { Financial } \\
\text { Planner } \\
n=777 \\
(22.24 \%)\end{array}$ & $\begin{array}{l}\text { Self-directed } \\
n=2,717 \\
(77.76 \%)\end{array}$ \\
\hline Sharpe ratio*** & 0.46 & 0.89 & 0.33 \\
\hline \multicolumn{4}{|l|}{ Economic Situations } \\
\hline Mean household income ${ }^{\star \star \star}$ & $\$ 98,202$ & $\$ 135,269$ & $\$ 87,602$ \\
\hline Mean household net worth ${ }^{\star \star \star}$ & $\$ 607,934$ & $\$ 920,275$ & $\$ 518,616$ \\
\hline Homeowner ${ }^{\star \star \star \star}$ & $31.31 \%$ & $20.40 \%$ & $34.43 \%$ \\
\hline Business owner** & $12.55 \%$ & $16.08 \%$ & $11.54 \%$ \\
\hline \multicolumn{4}{|l|}{ Demographic Characteristics } \\
\hline \multicolumn{4}{|l|}{ Age } \\
\hline Less than 35 years old ${ }^{\star \star \star}$ & $24.49 \%$ & $16.86 \%$ & $26.67 \%$ \\
\hline 35-44 years old & $15.17 \%$ & $14.69 \%$ & $15.30 \%$ \\
\hline $45-54$ years old & $20.04 \%$ & $22.40 \%$ & $19.36 \%$ \\
\hline 55-64 years old ${ }^{\star \star}$ & $19.19 \%$ & $22.65 \%$ & $18.21 \%$ \\
\hline $65-75$ years old & $12.71 \%$ & $14.63 \%$ & $12.16 \%$ \\
\hline More than 75 years old & $8.41 \%$ & $8.78 \%$ & $8.30 \%$ \\
\hline \multicolumn{4}{|l|}{ Gender } \\
\hline Female & $50.26 \%$ & $51.87 \%$ & $49.80 \%$ \\
\hline Male & $49.74 \%$ & $48.13 \%$ & $50.20 \%$ \\
\hline \multicolumn{4}{|l|}{ Race } \\
\hline White non-Hispanic ${ }^{\star \star \star}$ & $72.84 \%$ & $80.92 \%$ & $70.54 \%$ \\
\hline Black/African American ${ }^{\star \star}$ & $13.72 \%$ & $10.85 \%$ & $14.54 \%$ \\
\hline Hispanic ${ }^{\star \star \star}$ & $9.02 \%$ & $4.79 \%$ & $10.23 \%$ \\
\hline Other & $4.42 \%$ & $3.45 \%$ & $4.69 \%$ \\
\hline \multicolumn{4}{|l|}{ Education } \\
\hline No high school diploma/GED ${ }^{\star \star \star}$ & $6.84 \%$ & $2.27 \%$ & $8.15 \%$ \\
\hline High school diploma or GED ${ }^{\star \star}$ & $24.92 \%$ & $20.28 \%$ & $26.25 \%$ \\
\hline Some college & $27.09 \%$ & $24.95 \%$ & $27.70 \%$ \\
\hline Bachelor's degree $^{\star \star \star}$ & $24.39 \%$ & $30.42 \%$ & $22.66 \%$ \\
\hline $\begin{array}{l}\text { Graduate and Professional } \\
\text { degree }^{\star \star \star}\end{array}$ & $16.76 \%$ & $22.08 \%$ & $15.23 \%$ \\
\hline \multicolumn{4}{|l|}{ Marital status } \\
\hline Married/living with partner & $58.56 \%$ & $59.58 \%$ & $58.26 \%$ \\
\hline Not married & $41.44 \%$ & $40.42 \%$ & $41.74 \%$ \\
\hline \multicolumn{4}{|l|}{ Employment status } \\
\hline Employee & $60.48 \%$ & $57.93 \%$ & $61.21 \%$ \\
\hline Self-employed & $9.95 \%$ & $11.19 \%$ & $9.60 \%$ \\
\hline Retired & $23.89 \%$ & $24.60 \%$ & $23.69 \%$ \\
\hline Not working & $5.67 \%$ & $6.29 \%$ & $5.50 \%$ \\
\hline Having dependent children & $58.16 \%$ & $62.04 \%$ & $57.05 \%$ \\
\hline \multicolumn{4}{|c|}{ Respondents' Expectations/Preferences } \\
\hline \multicolumn{4}{|c|}{ Risk tolerance } \\
\hline No risk tolerance $e^{\star \star \star}$ & $37.93 \%$ & $24.71 \%$ & $41.71 \%$ \\
\hline Average risk tolerance $e^{\star \star \star}$ & $42.41 \%$ & $51.82 \%$ & $39.72 \%$ \\
\hline Above average risk tolerance ${ }^{\star \star}$ & $16.30 \%$ & $19.80 \%$ & $15.30 \%$ \\
\hline Substantial risk tolerance & $3.36 \%$ & $3.67 \%$ & $3.27 \%$ \\
\hline
\end{tabular}


TABLE 1: (continued)

\begin{tabular}{|c|c|c|c|}
\hline & \multirow[b]{2}{*}{$\begin{array}{l}\text { Total Sample } \\
N=3,494\end{array}$} & \multicolumn{2}{|c|}{ Information Source } \\
\hline & & $\begin{array}{l}\text { Financial } \\
\text { Planner } \\
n=777 \\
(22.24 \%)\end{array}$ & $\begin{array}{l}\text { Self-directed } \\
n=2,717 \\
(77.76 \%)\end{array}$ \\
\hline \multicolumn{4}{|l|}{ Investment horizon } \\
\hline Within a year ${ }^{\star \star \star}$ & $38.54 \%$ & $31.78 \%$ & $40.48 \%$ \\
\hline Next few years & $26.37 \%$ & $26.32 \%$ & $26.39 \%$ \\
\hline Next 5-10 years ${ }^{\star \star}$ & $22.21 \%$ & $26.09 \%$ & $21.11 \%$ \\
\hline Longer than 10 years ${ }^{\star \star}$ & $12.87 \%$ & $15.81 \%$ & $12.03 \%$ \\
\hline Expecting inheritance/gift* & $14.43 \%$ & $16.77 \%$ & $13.76 \%$ \\
\hline
\end{tabular}

NOTE: Analysis of the 2013 Survey of Consumer Finances; weighted results. ${ }^{*}$ Statistically significant difference between two information source user groups at an alpha level of .05 . "Statistically significant difference between two information source user groups at an alpha level of .01. "Statistically significant difference between two information source user groups at an alpha level of .001. 
TABLE 2: Ordered Logistic Analysis of Household Investment Portfolio Sharpe Ratio

\begin{tabular}{|c|c|c|c|}
\hline Parameter & $\begin{array}{l}\text { Reduced } \\
\text { Model }\end{array}$ & $\begin{array}{l}\text { Intermediate } \\
\text { Model }\end{array}$ & Full Model \\
\hline Intercept for the 2nd group & $-2.146^{\star \star \star}$ & $-2.163^{\star \star \star}$ & $-2.447^{\star \star \star}$ \\
\hline Intercept for the 3rd group & $-3.212^{\star \star \star}$ & $-3.229^{\star \star \star}$ & $-3.523^{\star \star \star}$ \\
\hline Intercept for the 4th group & $-4.546^{\star \star \star}$ & $-4.565^{\star \star \star}$ & $-4.871^{\star \star \star}$ \\
\hline Intercept for the 5th group & $-5.866^{\star \star \star}$ & $-5.885^{\star \star \star}$ & $-6.208^{\star \star \star}$ \\
\hline \multicolumn{4}{|l|}{ Economic situations } \\
\hline \multicolumn{4}{|l|}{ Household income (reference category = 1st quartile) } \\
\hline 2nd quartile & $0.764^{\star \star \star}$ & $0.762^{\star \star \star}$ & $0.765^{\star \star \star}$ \\
\hline 3rd quartile & $1.149^{\star \star \star}$ & $1.140^{\star \star \star}$ & $1.261^{\star \star \star}$ \\
\hline 4th quartile (highest) & $1.004^{\star \star \star}$ & $1.004^{\star \star \star}$ & $1.212^{\star \star \star}$ \\
\hline \multicolumn{4}{|l|}{ Household net worth (reference category = 1st quartile) } \\
\hline 2nd quartile & $0.924^{\star \star \star}$ & $0.927^{\star \star \star}$ & $1.006^{\star \star \star}$ \\
\hline 3rd quartile & $1.327^{\star \star \star}$ & $1.319^{\star \star \star}$ & $1.380^{\star \star \star}$ \\
\hline 4th quartile (highest) & $1.270^{\star \star \star}$ & $1.255^{\star \star \star}$ & $1.294^{\star \star \star}$ \\
\hline Renter (reference category = Homeowner) & 0.035 & 0.043 & 0.110 \\
\hline Business ownership (reference category $=$ no) & 0.209 & 0.206 & 0.248 \\
\hline \multicolumn{4}{|l|}{ Demographic characteristics } \\
\hline \multicolumn{4}{|l|}{ Age (reference category $=$ Less than 35 years old) } \\
\hline $35-44$ years old & 0.112 & 0.108 & 0.052 \\
\hline $45-54$ years old & 0.058 & 0.052 & -0.022 \\
\hline $55-64$ years old & 0.057 & 0.045 & 0.025 \\
\hline $65-75$ years old & 0.048 & 0.037 & -0.105 \\
\hline More than 75 years old & -0.014 & -0.022 & -0.105 \\
\hline Female (reference category = Male) & 0.123 & 0.117 & $0.218^{\star \star}$ \\
\hline \multicolumn{4}{|l|}{ Race (reference category = White, non-Hispanic) } \\
\hline Black/African American & $-0.250^{\star}$ & $-0.248^{\star}$ & -0.237 \\
\hline Hispanic & $-0.381^{\star \star}$ & $-0.379^{\star}$ & -0.267 \\
\hline Other & -0.198 & -0.184 & -0.102 \\
\hline \multicolumn{4}{|c|}{ Education (reference category = no high school diploma or GED) } \\
\hline High school diploma or GED & $0.327^{\star}$ & 0.319 & 0.327 \\
\hline Some college & $0.658^{\star \star \star}$ & $0.649^{\star \star \star}$ & $0.651^{\star \star}$ \\
\hline Bachelor's degree & $0.708^{\star \star \star}$ & $0.693^{\star \star \star}$ & $0.700^{\star \star}$ \\
\hline Graduate and professional degree & $0.862^{\star \star \star}$ & $0.845^{\star \star \star}$ & $0893^{\star \star \star}$ \\
\hline $\begin{array}{l}\text { Married/living with partner (reference category }=\text { not } \\
\text { married) }\end{array}$ & -0.075 & -0.072 & -0.060 \\
\hline Having dependent children (reference category $=$ no) & 0.070 & 0.066 & 0.061 \\
\hline \multicolumn{4}{|l|}{ Employment status (reference category $=$ not working) } \\
\hline Employees & $0.688^{\star \star \star}$ & $0.702^{\star \star \star}$ & $0.867^{\star \star \star}$ \\
\hline Self-employed & -0.140 & -0.124 & 0.073 \\
\hline Retired & 0.232 & 0.247 & 0.348 \\
\hline \multicolumn{4}{|l|}{ Respondents' expectations } \\
\hline \multicolumn{4}{|l|}{ Risk attitude (reference category $=$ no risk tolerance) } \\
\hline Average risk tolerance & $0.295^{\star \star \star}$ & $0.281^{\star \star}$ & $0.234^{*}$ \\
\hline Above average risk tolerance & 0.196 & 0.186 & 0.201 \\
\hline Substantial risk tolerance & -0.060 & -0.069 & -0.167 \\
\hline \multicolumn{4}{|c|}{ Investment horizon (reference category = within a year) } \\
\hline Next few years & $1.257^{\star \star \star}$ & $1.259^{\star \star \star}$ & $1.261^{\star * \star}$ \\
\hline Next $5-10$ years & $1.8656^{\star \star \star}$ & $1.857^{\star \star \star}$ & $1.788^{\star \star \star}$ \\
\hline Longer than 10 years & $2.420^{\star \star \star}$ & $2.425^{\star \star \star}$ & $2.339^{\star \star \star}$ \\
\hline Expecting inheritance/gift (reference category $=$ no) & -0.001 & -0.004 & 0.0060 \\
\hline $\begin{array}{l}\text { Use financial planners (reference category = self- } \\
\text { directed) }\end{array}$ & - & $0.148^{\star}$ & $1.581^{\star}$ \\
\hline
\end{tabular}


TABLE 2: (continued)

\begin{tabular}{|c|c|c|c|}
\hline Parameter & $\begin{array}{l}\text { Reduced } \\
\text { Model }\end{array}$ & $\begin{array}{l}\text { Intermediate } \\
\text { Model }\end{array}$ & Full Model \\
\hline 2nd income quartile $\times$ Planner & - & - & -0.035 \\
\hline 3rd income quartile $\times$ planner & - & - & -0.521 \\
\hline 4th income quartile $\times$ planner & - & - & $-0.799^{\star}$ \\
\hline 2nd net worth quartile $\times$ planner & - & - & -0.457 \\
\hline 3rd net worth quartile $\times$ planner & - & - & -0.398 \\
\hline 4th net worth quartile $\times$ planner & - & - & -0.285 \\
\hline Renter $\times$ planner & - & - & -0.461 \\
\hline Business ownership $\times$ planner & - & - & -0.113 \\
\hline 35-44 years old $\times$ planner & - & - & 0.325 \\
\hline 45-54 years old $\times$ planner & - & - & 0.366 \\
\hline 55-64 years old $\times$ planner & - & - & 0.225 \\
\hline $65-75$ years old $\times$ planner & - & - & 0.511 \\
\hline More than 75 years old $\times$ planner & - & - & 0.359 \\
\hline Female $\times$ planner & - & - & $-0.428^{\star}$ \\
\hline Black/African American $\times$ planner & - & - & -0.015 \\
\hline Hispanic $\times$ planner & - & - & -0.678 \\
\hline Other (including Asian) × planner & - & - & -0.455 \\
\hline High school diploma or GED $\times$ planner & - & - & -0.231 \\
\hline Some college $\times$ planner & - & - & -0.196 \\
\hline Bachelor's degree $\times$ planner & - & - & -0.237 \\
\hline Graduate and professional degree $\times$ planner & - & - & -0.357 \\
\hline Married/living with partner $\times$ planner & - & - & -0.123 \\
\hline Having children $\times$ planner & - & - & 0.057 \\
\hline Employees $\times$ planner & - & - & -0.612 \\
\hline Self-employed $\times$ planner & - & - & -0.743 \\
\hline Retired $\times$ planner & - & - & -0.392 \\
\hline Average risk tolerance $\times$ planner & - & - & -0.193 \\
\hline Above average risk tolerance $\times$ planner & - & - & 0.203 \\
\hline Substantial risk tolerance $\times$ planner & - & - & 0.008 \\
\hline Next few years $\times$ planner & - & - & 0.091 \\
\hline Next $5-10$ years $\times$ planner & - & - & 0.381 \\
\hline Longer than 10 years $\times$ planner & - & - & 0.418 \\
\hline Expecting inheritance/gift $\times$ planner & - & - & -0.237 \\
\hline
\end{tabular}

NOTE: Analysis of 2013 Survey of Consumer Finances; unweight results; using RII technique; sample size $=3,494 ;{ }^{*} p<.05 ; * * p<.01 ; * * * p<.001$. 